Бүкіл әлем елдерінің экономикалық өзара өсуі және банк бизнесінің трансформациясы, халықаралық қаржы қатынастарының күрделігінің арттуы және кеңейуінің нәтижесінің тұрғысында мынадай факторларға әсер етеді:

-ұлттық банк жүйелерінің халықаралық нарық капиталының өсуіне байланысты;

-әлемдік қаржы нарығындағы банктер мен басқа да қаржы институттары арасындағы бәсекелестіктің күшеюі;

-ұлттық экономиканың ашықтық дәрежесін арттыру;

-банктік стандарттауды қадағалау;

-ақпараттық және коммуникациялық технологияларды дамыту.

Жаһанданудың сондай-ақ халықаралық банктік бизнестің сипатына әсер етеді, банктік және қаржылық нарығын ырықтандыру процесін байқауға аса мән береді.

Банк ісінің әртүрлі түрлері қаржы қызметінің арасындағы институционалдық айырмашылықтарды жойады деген бірқатар жетекші ғалымдармен келіспеу мүмкін емес: коммерциялық, инвестициялық, сақтандыру. Бұл қаржы нарықтарындағы бәсекелестіктің сипаты мен нысандарының өзгеруіне әкеледі. Көптеген қаржы нарығының сегменттерінде бәсекелестік бір уақытта өседі.

Сонымен қатар бұрынғыдай банктік бәсекелестік банк жүйесінің тиімді жұмыс істеуін қамтамасыз ету үшін қуатты бақылау механизмі болып табылады. Банк бәсекелестерінде басқа банктер ғана емес, сондай-ақ, ырықтандыру кезіндегі резидент және резидент емес басқа да қаржы ұйымдары болып табылады. Ырықтандыру, сондай-ақ банктік бизнесті аумақтық әртараптандыруға әкеп соғады, және бүкіл әлемдегі халықаралық банк жағдайының жақсаруына ықпалын тигізеді.

Қорытындылай келе, Қазақстан Республикасы банктің секторының дамуы позитивті болуына қарамастан, жаһанданудың әсері банктік секторға өзінің үлкен әсерін тигізіп отырғанын байқауға болады.

\section{Пайдаланылған әдебиеттер:}

1. Теодор Левитт. Глобализация рынков

[Текст] / Андрей Минин //-2015г.

2. Мартинели М.Н, Бойченко А.В. Глобализация мирового хозяйства [Текст] / М.Н. Мартинели, А.В. Бойченко // М. учебное пособие под ред./ инфра-м. -2011-С. 5-6.

3. Назарбаев Н.Ә. Жахандану жағдайында Қазақстан республикасының әлемдік экономикаға интеграциялануы [Мәтін] / Ә.Н.Назарбаев //-2012.Б. -5.

4. Симонич Н. Глобализация и неровномерность мирового развития [Текст] / Симонич Н. // - №3- С. 35.

5. Э.Тирикьян Жаханданудың қазіргі теориялары [Текст] / Э.Тирикьян 2014

\title{
MANAGEMENT OF LENDING TO CLIENTS OF COMMERCIAL BANKS
}

DOI: $10.31618 /$ ESU.2413-9335.2019.9.62.148

Nurtazinova Akbayan Serikovna

Candidate of Economic Sciences. Associate Professor of Economics and Law at the University of Zhezkazgan

Daukenova Gauhar Amanzholovna

Candidate of Economic Sciences. Associate Professor of Economics and Law at the University of Zhezkazgan

Akbergenova Akmaral Kaisarovna

Master of Economics. Teacher of Ekonomics and Law at the University of Zhezkazgan

Akubaeva Bagdat Askanovna

Master of Economics. Teacher of Ekonomics and Law at the University of Zhezkazgan

\section{КОММЕРЦИЯЛЫК БАНКТЕРДІН КЛИЕНТТЕРІН НЕСИЕЛЕУ БАРЫСЫНДАҒЫ МӘСЕЛЕЛЕРДІ БАСКАРУ}

Нұртазинова Ақбаян Серікқызы

Экономика выльммдарының кандидаты, Ө.А.Байқуоңыров атындавы Жезқ̧азван университетінің доиенті, Жезқ̧азван қ̧аласы

Даукенова Гаухар Аманжоловна

Экономика гылымдарының кандидаты, Ө.А.Байқуоңьыров атындавы Жезқ̧аздан университетінің доиенті, Жезқ̧азван қ̧аласы

Ақбергенова Ақмарал Қайсаровна

Экономика гыльымдарының магистрі, Ө.А.Байқұнңыров атындагы Жезқ̧аздан университетінің, оқытушысы, Жезқаздан қ̧аласы

Акубаева Бавдат Аскановна

Экономика вылымдарының магистрі, Ө.А.Байқуоңыров атындавы Жезқ̧аздан университетінің оқытушысы, Жезқ̧аздан қ̧аласы 
SUMMARY.

Article development of lending and management of problems in lending in banks by assessing the overall level of creditworthiness of customers, all borrowers and describing the degree of risks closely related to the financial values provided to a particular borrower in banks.

АНДАТПА.

Мақала коммерциялық банктердегі клиенттердің, барлық несие алушылардың несиелік қабілетінің жалпы деңгейін бағалау мен банктердегі нақты несие алушыға беретін қаржы шамасымен тығыз байланысты тәуекелдерінің дәрежесін сипаттау арқылы банктердегі несиелеу барысындағы кездесетін қиындықтарды басқарып, несиелендіруді дамыту.

Key words: commercial banks, credit operations, loan portfolio, risk management.

Түйін сөздер: коммерциялық банктер, несиелік операция, несие қоржыны, тәуекелді басқару.

\section{Kipicne}

Коммерциялық банктердің клиенттерін тиімді әрі тез несиелеу барысындағы мәселелерді басқаруда ең алдымен әр түрлі несие түрлері бойынша барлық клиенттер үшін бір ғана әдісті несиелік қабілеттілікті талдау әдісін қолдану қате, қазіргі таңда қарыз алушының несиелік қабілеттілігін кешенді талдауды қарастыру керек.

Қазақстандағы коммерциялық банктердегі қарыз алушының несиелік қабілеті мен қаржылық жағдайын кешенді бағалау және несиелік операцияларға байланысты шығындар мен залалдарды ескеру, банкке несиелік ресурстарды тиімді басқаруға және пайда табуға итермелейді.

Сондықтан бұл мақалада келесідей міндеттерді шешу көзделген:

- Қазақстандағы коммерциялық банктердегі несие алушының төлем қабілеттілігін толық сипаттайтын көрсеткіштерді бағалау және талдау, несие беру процесіндегі мәселелерді анықтау;

Коммерциялық банктердегі қарыз алушыларының несиелік қабілетін толық тануға мүмкіндік беретін несиелік операцияларын бағалау, салыстыру олардың банктің табысына тигізетін әсерін айқындау;

- Ұлттық Банк арқылы жүргізілетін коммерциялық банктердің несие қабілеттілігі өзгерісіне нақты әсерін тигізетін қаулылар мен заңдардағы өзгерістерді бағалау.

\section{Тәжірибелік бөлім}

Өткен уақытта «несиелік қабілеттілік» ұғымы болған жоқ. Бұл жағдай тауар-ақша қатынастарына ұзақ мерзімді шек қоюмен түсіндірілетін. Сонымен қатар тікелей банктік несиелер нысанында дамып жатқан несие қатынастарына экономикалық емес, әкімшілік басқару әдісі сипатында болуы негіз болды.

Банктердің несиесін өтей алмауды тудыратын ықпалдарды немесе мерзім бойынша өтеуді қамтамасыз ету ықпалдарын зерттеу несие қабілеттілікті талдау мазмұнын қарастырады.

Несиелік қабілеттілікті талдау кезінде банктер келесі сұрақтарға жауап беруі қажет: қарыз алушы міндеттемелерді уақытылы орындай ала ма, сол міндеттемелерді орындауға даяр ма?

Бірінші сұраққа жауапты қарыз алушының қаржы-шаруашылық талдау есебі жауап береді. Ал екінші сұрақ, заңды нысанды иелену арқылы қарыз алушының жекелей қасиеттерімен байланысады.

Банк клиенттерінің несиелік қабілетін бағалау критерийлері несиелік қабілеттілікті бағалау тәсілдерінің мазмұнын анықтайды.

Кең тараған осындай тәсілдер қатарына жататындар:

- Қаржылық коэффициенттерді бағалау;

- ақша ағынын талдау;

- іскерлік тәуекелді бағалау;

- менеджментті бағалау; қарыз алушының қаржылық тұрақтылығын бағалау; қарыз алушы туралы ақпараттар жинау;

- орналасқан жеріне бару арқылы қарыз алушының жұмысын қадағалап отыру.

Жалпы клиенттердің несиелік қабілеттіліктерін анықтау мәселелері революцияға дейін және одан кейінгі 20-шы жылдардың экономикалық әдебиеттерінде кеңінен зерттелгендігін байқауға болады.

Негізінен клиенттердің несиелік қабілеттілігі ұғымы негізінен екі бағытта қарастырылған: мысалы несиелеу субъектісі тұрғысынан алып қарағанда - несиелік мәміле жасай алу мүмкіндігі мен несиені дер кезінде және толығымен қайтару ықтималдылығы, банк тарапынан алғанда - несие берудің мүмкін болатын көлемін анықтау[1].

Несиелік қабілеттілікті анықтауда қаржылық мүмкіндіктер, нақтылық, шаруашылықтың жағдайларға төзімділігі мен беріктігі, іс жүргізу мен есптеулердің дұрыстығы сияқты несиелік қабілеттілікті анықтаудың көптеген көрсеткіштері қолданылып отырған.

\section{Нәтижелер мен талқылаулар}

Несие бойынша банктердің жалпы жағдайын бағалау, әрі қарай қандай бағыттарда жұмыс жасау қажеттілігін көрсетеді. 2018 жылғы 1 қаңтардағы статистикалық мәліметтер бойынша Қазақстан Республикасында 32 банк және банк операцияларының жекелеген түрлерін жүзеге асыратын 6 ұйым, оның ішінде 2 ипотекалық ұйым болды, ал алдыңғы өткен 2017 жылдың басында 33 банк және банк операцияларының жекелеген түрлерін жүзеге асыратын 8 ұйым, оның ішінде 3 ипотекалық ұйым жұмыс істеген [2].

2017 жылы банк секторының активтері 1,4 трлн теңгеге немесе 5,5\%-ға азайды және 24,2 трлн теңге болды (1-сурет). 


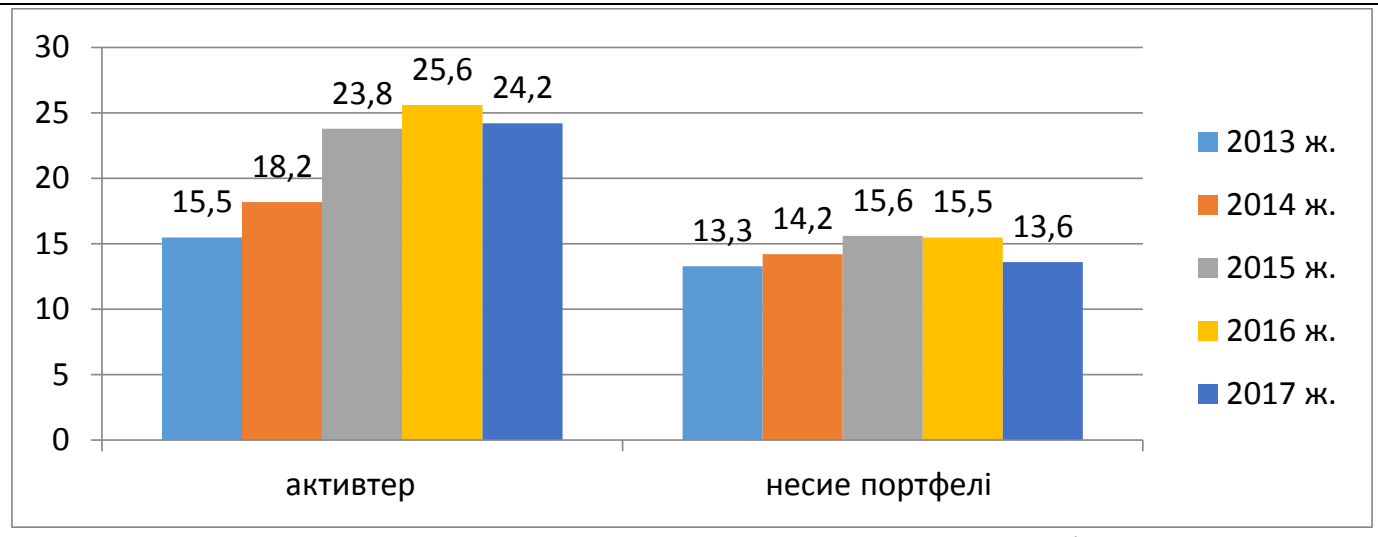

1 сурет - Коммеричялық банктердің активтері мен несие портфелінің серпіні (трлн. тенгемен)

*дерек көзі- [3] ддебиет көзіне сүйене отырып, авторменен құрастырылван

Қаржылық мәліметтерге сай банк секторының несие портфелі жылдың басынан бастап 12,4\%-ға азайып, 2017 жылдың қорытындылары бойынша 13,6 трлн теңге болды [4].

2018 жылғы 1 қаңтардағы жағдай бойынша банк секторының несие портфелі бойынша халықаралық $\begin{array}{lrr}\text { стандарттарының } & \text { талаптарына } & \text { сәйкес } \\ \text { қалыптастырылған провизиялар } 2,1 & \text { трлн } & \text { теңге }\end{array}$ немесе жиынтық несие портфелінің 15,6\%-ы болды.

Ұлттық валютамен несиелер 2017 жылы 9,4 трлн теңгеге дейін 9,2\%- ға ұлғайды, ал шетел валютасымен несиелер 3,3 трлн теңгеге дейін 19,2\%-ға төмендеген.

Нәтижесінде теңгемен берілген несиелердің жалпы көлемдегі үлес салмағы 67,5\%-дан 73,7\%-ға дейін көтерілді.

Заңды тұлғаларға несиелер көлемі 2017 жылдың қорытындысы бойынша 8,2 трлн теңге құрап, 5,8\%-ға дейін төмендеді, ал жеке тұлғаларға несиелер 4,5 трлн теңгеге дейін 12,4\%-ға ұлғайды. Жеке тұлғаларға несиелердің үлес салмағы 31,8\%дан 35,7\%-ға дейін ұлғайды.

Ұзақ мерзімді несиелеу 2017 жылы 10,8 трлн теңгеге дейін 2,9\%-ға ұлғайды, қысқа мерзімді несиелеу 1,9 трлн теңгеге дейін $14,0 \%$-ға азайды. Банктердің несиелік портфелінің құрылымындағы ұзақ мерзімді несиелердің үлесі 85,0\%-ды құрады (2016 жылғы желтоқсанда - 82,6\%). Шағын кәсіпкерлік субъектілеріне несие беру 2017 жылы 2,8 трлн теңгеге дейін 7,1\%-ға азайды, бұл экономикаға несиелердің жалпы көлемінің 21,9\%ын құрайды.

Коммерциялық банктердің шығындары мен несиелік саясатын, бағдарламаларын сапалы деңгейде басқару коммерциялық банктің ұзақ мерзімді перспективадағы табыстарға қол жеткізу мүмкіндіктерін көрсетеді. Банк операцияларының басым бөлігі несиелік қызметпен байланысты. Сондықтан да, несиелік мәселелерді басқару банктің қаржылық жағдайын қамтамасыз етудің ең маңызды жолы болып табылады.

Зерттеу барысында қарастырылған анықтамалардың біреуі де несие тәуекелділігін себебі мен нәтижесі бар белгілі бір үрдіс ретінде сипаттамайды, сондықтан несие тәуекелділігін дұрыс жіктеу оларды тиімді басқаруға мүмкіндік береді деп есептеп, несие тәуекелділігінің жаңа жіктемесі енгізілді.

Тәуекелді басқару - бұл өзіне: тәуекелдерді болжауды, олардың мөлшері мен әсерін анықтауды, олардың алдын алу немесе олармен байланысты залалдарды төмендетуге арналған ісшараларды дайындау мен жүзеге асыруды біріктіретін үрдіс.

Банктің несие тәуекелділігі сыртқы ортамен қатар ішкі орта факторларына да тәуелді, сол себепті біреуіне ғана кеңірек көңіл бөліп (әдетте, сыртқы факторлар әсерінен болатын тәуекелдер қауіпті саналады), екіншісіне үстіртін қарауға болмайды.

Несиелік қабілетті бағалауда екінші деңгейлі банк қызметкерлерінің көп жылғы деректер базасын қолдана отырып, не клиенттің қаржылық жағдайын бағалай отырып, қаржылық тұрғыдан бағалау, сонымен қатар математикалықстатистикалық әдістер мен тәсілдер көмегімен несиелік қабілетті бағалау жүйелерін пайдаланудың кешенді бағыттарын қолдануларымыз қажет.

Қазіргі таңда тұрғын үй үшін берілетін ипотекалық несие тәуекелі жоғары болып табылатындықтан ол тәуекел түрін мына нәтижелерге байланысты көрсетуге болады:

- несие мамандарының клиент нәтижелерін дұрыс анықтамауы;

Несие мамандары қаржылық және нарықтық көрсеткіштерді, банк қызметінің, сондай-ақ банк клиентінің болашағын дұрыс бағаламау салдарынан бүгінгі таңда әртүрлі тәуекелдерін жоғары деңгейде басқара алмай да отыр.

Коммерциялық банктердің қарыз алушының несие қабілеттілігін басқару мен талдау ісі аса мұқияттылық пен уақытты қажет етеді.

Бүгінгі таңда қарыз алушыны тексеру шамамен 1 күннен 25 күнге дейінгі уақыт алытыны дәлелденіп отыр, және бұл кезең қарыз алушыны толық тексеруге мүмкіндік береді. 
Банктердегі қарыз алушының несие қабілетін анықтауда ақпараттық басқарудың негізгі бағыттары төмендегілер:

- алынатын несие бойынша тәуекелдерін анықтауға тиімді әсер ететін қаржылық ақпараттарды толық жинау;

- банк клиентінің несие алушы туралы ақпараттық базаны құру арқылы несие алушылардың қаржылық жағдайын басқару бойынша жұмыстарды жаңартып отыру, базаны толықтыру мен жетілдіру;

- кейбір коммерциялық банктердің «қара тізіміне» енген клиенттерді базада ұстау мен оларды қадағалап отыру;

- банктердегі статистикалық салыстырмалы талдаулар жасау үшін көп жылғы деректерді пайдалану, яғни тек 1 немесе 2 жыл көлеміндегі статистикалық деректерді пайдаланбай, 5-10 жыл көлеміндегі статистикалық деректерді пайдалану;

- статистикалық деректердің қасақана өзгерту арқылы болатын заң бұзушылықтарды болдырмау.

- клиент не несие алушылардың тұрақты жұмыс орнынан алынатын анықтамалардың рас екендігіне көз жеткізу;

- банктердегі несие алушылардың тек қазіргі қаржылық жағдайына бақылау орнатпай, алдынала ұзақ уақытқа болжамдар жасау, бұрынғы капиталы мен алдағы жылдардағы қаржылық жағдайын салыстыру;

Мысалы, Ресей елінде банктегі қарыз алушының несиелік қабілетін бағалауда болжамдық негізде математикалық үлгілерге негізделген жүйемен қатар несие алушылардың базасын құру мен оны пайдалану бойынша шаралар кеңінен қолданылады. Бұл көптеген банктер үшін сенімді және тиімді.

Ал бүгінгі банктер үшін танымал үлгінің бірі, «негізігі скоринг үлгісі», осындай математикалық үлгілердің көмегімен алгоритмдерді пайдалана отырып, несиелік тәуекелді өлшеудің және бағалаудың кең танылған үлгілерінің бірі.

Несиелік тәуекелдерді басқарудағы ескеретін жағдай несие тәуекелдері сыртқы экономикалық жағдайлармен тығыз байланысты. Халықаралық несие ісінде Үкіметтік шеңбердегі келісімдер мен меморандумдарға қол қойылады.

Сонымен қатар халықаралық дамыған экономика жағдайында тәуекелдер туындауы ықтималдығы өте жоғары, бұл тәуекелдер коммерциялық және елдік болып бөлінеді [5].

Мұндай жағдайларда тәуекелдерді басқаруда орталық банк, экономика және қаржы министрлігінің ақпараттары пайдаланылады.

Қарызды жеке тұлғаға беру жағдайында дебитор туралы мәліметтер неғұрлым терең сұралады. Көбінесе консорциумның жұмысшылары мен қызметкерлері қарыз алушының шарашылық қызметін кемінде соңғы 5 жыл мерзімге сұрап алады.

Қарыз алушының қаржылық жағдайын бағалауда дебитордың қаржылық іс-әрекеті, баланстағы және одан тыс қаржылық жағдайы әртүрлі құжаттардың көмегімен талданады. Өзіндік және тартылған қаражаттарының көлемі салыстырылады, негізгі және айналмалы қорлары бағаланады. Ал егер қарыз алушы сенімді болып танылмаса, жедел түрде қарыз мөлшері төмендетіледі [5].

Несиелік қабілетті анықтаудың маңызды элементі банктегі бақылауды ұйымдастыру болып табылады (потенциалды қарыз алушыны несиелеу мүмкіндігі туралы сұрақты шешу барысында несиелік ережелерді дұрыс қолдануға бақылау жасау.

Коммерциялык банктердегі клиент-зацды тулғалардыц несие кабілетін аныктаудыц шиамала

\begin{tabular}{|c|c|c|}
\hline $\begin{array}{l}\text { Қаржылық } \\
\text { жағдайын талдау }\end{array}$ & $\begin{array}{c}\text { Қаржылық жағдайын жалпы бағалау } \\
\text { көрсеткіштері }\end{array}$ & Есептеу формулалары \\
\hline $\mathrm{X} 1$ & CAGR -меншікті капиталының өсуі темпі & $(\mathrm{CK \backslash CK})-1$ \\
\hline $\mathrm{X} 2$ & $\begin{array}{l}\text { CAGR-Бір жұмысшыға келетін өнімді } \\
\text { сатудан түскен кіріс көлемінің артуы }\end{array}$ & $\begin{array}{l}\text { Бір жұмысшыға келетін } \\
\text { өнімді сатудан түскен кіріс } \\
\text { көлемінің артуы жыл бойына। } \\
\text { жұмыспен қамтылғандардын } \\
\text { жыл бойынғы орташа саны }\end{array}$ \\
\hline $\mathrm{X} 3$ & $\begin{array}{l}\text { CAGR-Бір жұмысшыға келетін өнімді } \\
\text { сатудан түскен кіріс көлемінің артуы }\end{array}$ & $\begin{array}{l}\text { (Бір жұмысшыға келетін } \\
\text { өнімді сатудан түскен кіріс } \\
\text { көлемінің артуы жыл бойына) } \\
\text { жұмыспен қамтылғандардың } \\
\text { жыл бойынғы орташа саны) -1 }\end{array}$ \\
\hline
\end{tabular}

Сонымен қатар кредиттік қабілеттілікті анықтауда қылмыстық жолмен қаржы құжаттарын жасайтын алаяқтар да бар.

Банктердегі несие саласындағы ұйымдастырылған қылмыстың дайындық кезеңінің жүзеге асу механизмі негізінен басты мынадай ерекшеліктерге ие:
1. коммерциялық банк жүйесіндегі ұйымдасқан әрекеттердің болуы мен жоспарланған сипатының болуы;

2. банк қызметінің алғашқы кезеңде тек заңды экономкалық кәсіпкерлік қызмет түрімен айналысқан болып көрініп, кейіннен өзгерістерге ұшырау. 
Көптеген банктер несие тарихын пайдалануда және қалыптастыруда клиенттің әлеуметтік сипатына, өткен кезеңдердегі банкпен қатынастарының нәтижелеріне басты назар аударады.

Ал керісінше кез-келген клиентке несие беріп, несие алушының несие тарихына назар аудармаған не қажет деп таппаған, тек бүгінгі күннің табысына қызмет жасаған банктер бүгінгі таңда үлкен шығындарға ұшырап отыр.

Ал егер несие алушы жеке тұлға емес заңда тұлға болып танылатын болса, онда қандай қаржылық көрстекіштер қолданылуы қажет екендігіне назар аударамыз:

Қарыз алушы - кәсіпорынның қаржылық жағдайын бағалауда мынадай қаржылық көрсеткіштер есепке алынады, бұл туралы 2-ші кестеде беріліп отыр. 2-ші кестеде берілгендей балансталған көрсеткіштер жүйесінің негізіндегі стратегиялық карта жүйесінің интеграциялану тұжырымдамасы бұл банктің ұзақ мерзімді мақсаттары мен оперативті бизнесін және оларға жету жағдайын бақылауды жүзеге асыратын келісу әдісі .

Банк қызметкерлері қаржылық және нарықтық көрсеткіштерді, банк қызметінің, сондай-ақ банк клиентінің болашағын дұрыс бағаламау салдарынан бүгінгі таңда әртүрлі тәуекелдерін жоғары деңгейде басқара алмай да отыр.

Қарыз алушының несие қабілеттілігін басқару мен талдау ісі аса мұқияттылық пен уақытты қажет етеді. Бүгінгі таңда қарыз алушыны тексеру шамамен 1 күннен 25 күнге дейінгі уақыт алатыны дәлелденіп отыр, және бұл кезең қарыз алушыны толық тексеруге мүмкіндік береді.

2 кесте

Банктердегі заңды тұлғалардың кредит қабілетін анықтаудың шамалары

\begin{tabular}{|c|c|c|c|}
\hline $\begin{array}{l}\text { Қаржылық } \\
\text { жағдайын } \\
\text { әдістері }\end{array}$ & \begin{tabular}{lr}
\multicolumn{1}{c}{ Қаржылық } & $\begin{array}{c}\text { жағдайын } \\
\text { жалпы }\end{array}$ \\
көрсеткіштері & \\
\end{tabular} & $\begin{array}{r}\text { Өтімділік } \\
\text { көрсеткіштері }\end{array}$ & $\begin{array}{c}\text { Қаржылық } \\
\text { тұрақтылық көрсеткіштері }\end{array}$ \\
\hline $\begin{array}{l}\text { Мәліметтерді } \\
\text { құрылымды талдау }\end{array}$ & $\begin{array}{c}\text { Кәсіпорынның } \\
\text { жарғылық капиталы }\end{array}$ & \begin{tabular}{l}
\multicolumn{1}{c}{ Ағымдағы } \\
өтімділік \\
коэфициенттері
\end{tabular} & 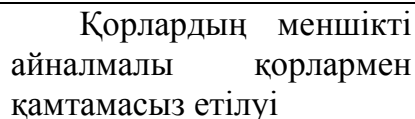 \\
\hline $\begin{array}{l}\text { Вертикальды } \\
\text { (құрылымдық) } \\
\text { талдау } \\
\end{array}$ & \begin{tabular}{l}
\multicolumn{1}{c}{ Айналмалы } \\
қорлары(өндірістік \\
запастар)
\end{tabular} & \begin{tabular}{l}
\multicolumn{1}{c}{ Мерзімді } \\
өтімділік \\
коэфициенттері
\end{tabular} & $\begin{array}{lr}\text { Негізгі } & \text { құралдармен } \\
\text { қамтамасыз } & \text { етілу } \\
\text { коэфициенті } & \\
\end{array}$ \\
\hline $\begin{array}{l}\text { Сай ұрылымдық } \\
\text { талдаулар }\end{array}$ & 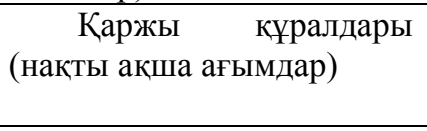 & $\begin{array}{l}\text { Тез өтімділік } \\
\text { коэфициенттер }\end{array}$ & \begin{tabular}{lr}
\multicolumn{1}{c}{ Өзіндік } & және \\
тартылған & қаражаттар \\
қатынасының коэфициенті
\end{tabular} \\
\hline $\begin{array}{l}\text { Салыстырмалы } \\
\text { талдаулар }\end{array}$ & $\begin{array}{l}\text { Кәсіпорынның дайын } \\
\text { өнімдері }\end{array}$ & $\begin{array}{l}\text { Абсалютті } \\
\text { өтімділік } \\
\text { коэфициенті }\end{array}$ & $\begin{array}{l}\text { Тез айналымдылық } \\
\text { коэфициенті }\end{array}$ \\
\hline $\begin{array}{l}\text { Құрылымдық } \\
\text { талдау }\end{array}$ & $\begin{array}{l}\text { Акционерлік } \\
\text { капиталы }\end{array}$ & - & $\begin{array}{l}\text { Жеке ерекшіліктер } \\
\text { коэфициенттері }\end{array}$ \\
\hline
\end{tabular}

Қарыз алушының несие қабілеттілігін басқару мен талдау ісі аса мұқияттылық пен уақытты қажет етеді. Бүгінгі таңда қарыз алушыны тексеру шамамен 1 күннен 25 күнге дейінгі уақыт алатыны алады, бірақ бағдарламада арнайы мақсатты мүмкіндіктерін дұрыс болжай да алмайды. дәлелденіп отыр, және бұл кезең қарыз алушыны толық тексеруге мүмкіндік береді.

Кей жағдайларда зәру мұқтаждықтар үшін клиент қажетті соманы ең қысқа мерзімде ала жұмсау көрсетілмейтіндіктен, олар өз қаржылық

\section{Сыйақы мөлшерлемелері}

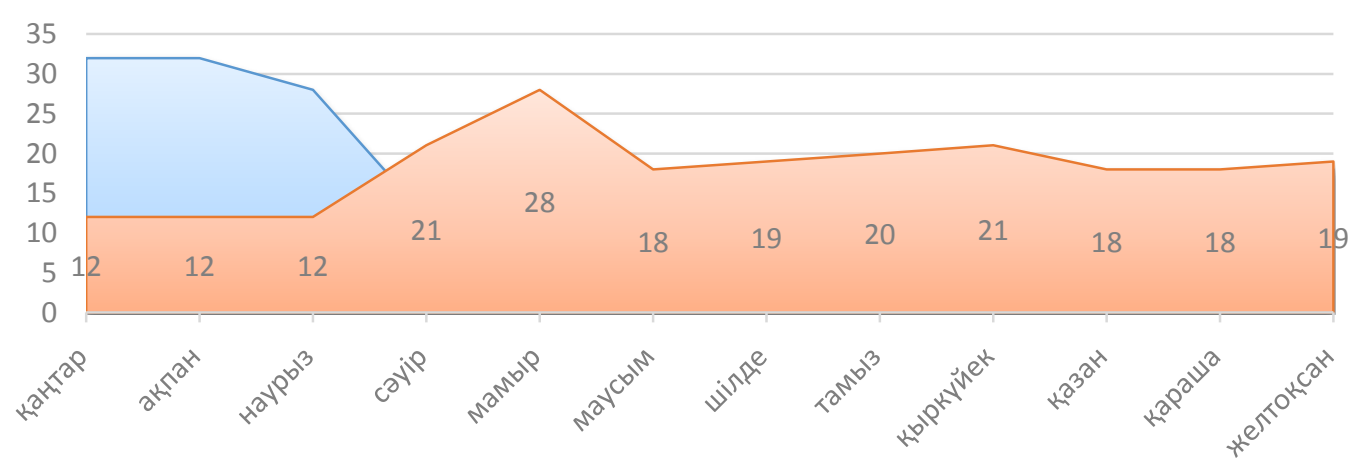

Сурет 3. 2017 жылы теңзеемен мерзімді депозиттер бойынша сыйақы мөлшерлемесінің серпіні 
Жалпы банк секторында салымдардың құрылымы өсуімен байланысты банк секторы міндеттемелері де артып келеді. 4).

Төменде 4-ші суретте ҚР банк секторының жалпы міндеттемелері төмендегідей беріліп отыр (сурет

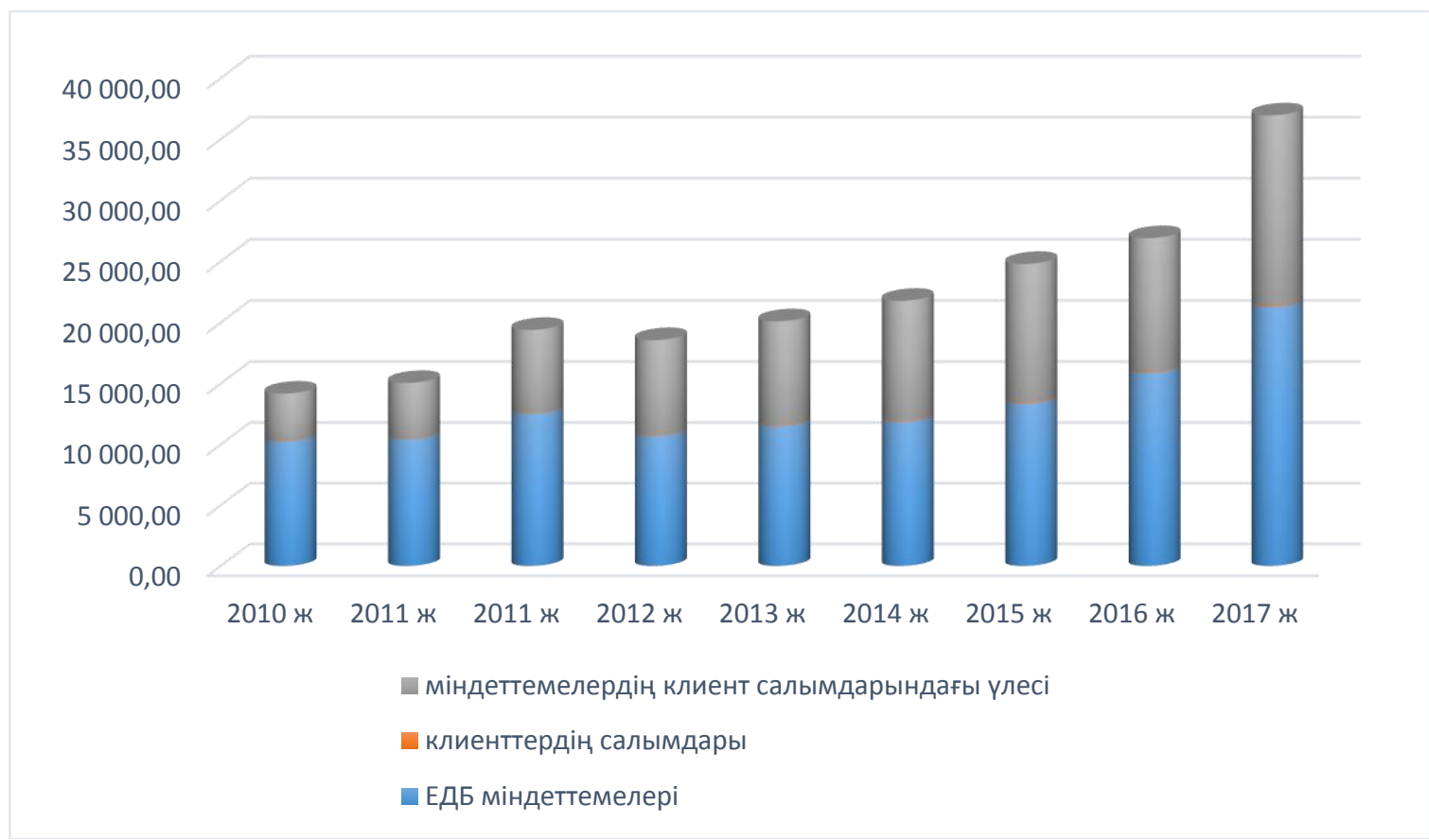

Сурет 4. Коммеричиялқ банктердегі банк міндеттемелерінің өзгерістері

Қазақстандағы салымдардың жалпы деңгейі соңғы кездерде барынша өзгерді, алайда банктердегі жеке тұлғалардың салымдарды артты, ал заңды тұлғалардың салымдары құрылымы өзгерген жоқ.

\section{Қорытынды}

Тәжірибе көрсеткендей, көптеген банкілерде несиені қайтаруды қамтамасыз ету мәселесі жоғары маңыздылыққа ие болып тұрғанымен, әлі де несиелік тәуекелді басқару жүйесін құруға онша мән берілмейді. Мұндай жағдайда банктің несие тіуекелін басқару жүйесін өзгертудің негізгі бағыттары ретінде төмендегі бағыттарды алған жөн. Бұл бағыттар несиелік тәуекелді басқару жүйесін жетілдіре түседі [7]. Негізгі бағыттар:

- отандық банк тәжірибесіне халықаралық несие беру тәжірибесін кіргізіп, бейімделу;

- банктің несие тәуекелін басқару жүйесін несиенің мәнді шегін және банктің несие тәуекелінің өзгешелігін есепке ала отырып құру;

- несие принциптерінің орындалуын қамтамасыз ету (қайтарымдылығы, еріктілігі, жеделдігі, ақылы, қаржының мақсатты бағытқа берілуін қамтамасыз ету);

- банк қызметі нарығының сұранысына сәйкес несие берудің жаңа формаларын дамыту, сондай-ақ бұл жерде несие беруші банктің және несие алушының мүддесі есепке алынуы тиіс;
- несие тәуекелдігі басқару құрылымын өзгерту және несие процесін ықшамдау;

- банк несиесін пайдалануды қадағалау функциясын банк тарапынан күшейту.

\section{Пайдаланылған әдебиеттер:}

1. С.Б.Мақыш, Л.А.Шоманова. Қазақстан экономикасының нақты секторын кредиттеу жағдайы және болашағы // ҚазҰУ хабаршысы. Экономика сериясы №6 (46), 2011 ж 48 бет.

2. ҚР Ұлттық банкінің жылдық қаржылық есептемелері, 2018 ж.

3. ҚР Ұлттық банкінің жылдық қаржылық есептемелері, 2017 ж.

4. ҚР Ұлттық банкінің жылдық қаржылық есептемелері, 2019 ж.

5. И.В.Ларионова Управление активами и пассивами в коммерческом банке. М., Издательство "Консалтбанкир" 2011 г.

6. Ситуков С.А., Голышев В.Д. «Банктік аудитке кіріспе»: -М: Гаврев, 2011, С128.

7. Нуртазинова А.С., Несиелік тәуекелменеджментінің банктің несиелік портфелінің сапасын арттыруға ықпалы (Қазақстан Республикасы екінші деңгейдегі банктер материалдары негізінде): -Алматы: Автореферат,2010ж,21Б. 